\title{
HUBUNGAN KOMPETENSI SOSIAL GURU KRISTEN TERHADAP PERKEMBANGAN KARAKTER SISWA: TANTANGAN PENDIDIKAN KRISTEN DALAM MENCERDASKAN YOUTH GENERATION
}

\author{
Made Astika ${ }^{1)^{*}}$ Selviyanti Sari Bunga ${ }^{2)}$ \\ 1) Dosen Pascasarjana Magister Pendidikan Agama Kristen Sekolah Tinggi Theologia Jaffray \\ ${ }^{2)}$ Alumni Magister Pendidikan Agama Kristen Sekolah Tinggi Theologia Jaffray \\ *)Penulis korespondensi: made.astika@sttjaffray.ac.id
}

\begin{abstract}
Abstrak
Tulisan ini bertujuan melihat hubungan kompetensi sosial guru Kristen dan karakter siswa melalui penelitian yang dapat menjawab tantangan pendidikan Kristen dalam mencerdaskan generasi muda yang dikenal juga sebagai Youth Generation (Generasi Y). Pengaruh kompetensi sosial guru yang mencakup kemampuan berkomunikasi, penggunaan teknologi informasi dan komunikasi, serta pengetahuan umum dapat memengaruhi karakter siswa yang berdampak pada kecerdasan siswa. Hasil studi ini menunjukkan bahwa kompetensi sosial guru Kristen untuk penguasaan teknologi informasi dan komunikasi perlu ditingkatkan supaya guru dapat memberi pengaruh positif terhadap perkembangan siswa dan pergaulan yang efektif guru-siswa melalui komunikasi, teknologi informasi dapat mencapai tujuan pendidikan Kristen.

Kata-kata kunci: kompetensi sosial, guru, Kristen, siswa, pendidikan, pemuda, Youth Generation

The purpose of this writing is to see the relationship of the social competence of Christian teachers and the character of the students through research that is able to answer the challenge of Christian education through educating the younger generation also known as Youth Geneneration (Y Generation). The influence of the social competence of a teacher includes the ability to communicate, the use of technology for information and communication, along with a general knowledge that can influence the character of the student that impacts a student's intellect. The results of this study show that the social competence of a Christian teacher for the mastery of informational technology and communication needs to be increased so that the teacher can have a postive influence on the development of the student and effective student-teacher association through communication, informational technology so that purpose of Christian education can be achieved.
\end{abstract}

Keywords: Social Competence, teahcer, Christian, student, education, young person, Youth Generation. 


\section{Pendahuluan}

Tujuan pendidikan nasional yang pada dasarnya untuk mencerdaskan anak bangsa menjadi tantangan bagi pelaksanaan pendidikan. Definisi pendidikan dituangkan dalam UU No. 2 Tahun 1989 tentang Sistem Pendidikan Nasional mendefinisikan bahwa "Pendidikan adalah usaha sadar untuk menyiapkan peserta didik melalui kegiatan bimbingan, pengajaran, dan atau latihan bagi peranannya di masa yang akan datang." Selanjutnya dalam pengembangannya yang tertuang dalam UU No. 20 Tahun 2003 dikatakan bahwa pendidikan adalah usaha sadar dan terencana untuk mewujudkan suasana belajar dan proses pembelajaran agar peserta didik secara aktif mengembangkan potensi dirinya untuk memiliki kekuatan spiritual keagamaan, pengendalian diri, kepribadian, kecerdasan, akhlak mulia, serta keterampilan yang diperlukan dirinya dan masyarakat. ${ }^{1}$

Tantangan pendidikan Kristen saat ini diperhadapkan dengan kemajuan zaman di bidang pengetahuan dan teknologi yang berkembang pesat. Informasi dunia yang dapat diakses dengan mudah dan murah oleh siapa saja melalui genggaman tangan, menjadi tantangan yang kompleks bagi pendidik dalam mendidik anak didik terutama dalam perkembangan karakter yang disesuaikan dengan asas-asas yang berlandaskan sumber kebenaran firman Allah yaitu Alkitab.

Berdasarkan tugas, fungsi dan tanggung jawabnya, guru PAK dalam pekerjaan dan jabatannya dituntut untuk memiliki beberapa kompetensi antara lain: Kompetensi Pedagogik, kepribadian, sosial dan kompetensi professional. Sebagai pendidik, sudah sepatutnya guru PAK berupaya untuk meningkatkan kompetensinya dalam melaksanakan pelayanan pendidikan.

\section{Definisi Kompetensi Sosial Guru}

Kompetensi sosial digambarkan sebagai hal yang melibatkan pengetahuan dan keterampilan secara pribadi yang mana orang tersebut berkembang untuk menangani secara efektif kehidupan dengan banyak pilihan, tantangan, dan peluang. ${ }^{2}$ Kompetensi sosial seorang guru berbicara tentang bagaimana guru mampu berkomunikasi, bersosialisasi

\footnotetext{
${ }^{1}$ Definisi Pendidikan berdasarkan UU No. 2 Tahun 1989 tentang Sisdiknas; dan UU No. 20 Tahun 2003 tentang Sisdiknas.

${ }^{2}$ Heejeong Sophia Han and Kristen Mary Kemple, "Components of Social Competence and Strategies of Support: Considering What to Teach and How," Early Childhood Education Journal 34, No. 3 (December 2006): 24l; N. Leffert, P. L. Benson \& J. L. Roehlkepartan, Starting out right: Developmental assets for children (Minneapolis, MN: Search Institute, 1997).
} 
dan berinteraksi sosial dengan murid-murid, sesama guru, orang tua, dan juga masyarakat serta pengetahuan umum. Salah satu kompetensi yang harus dimiliki oleh guru dalam kompetensi sosial ialah juga menggunakan teknologi komunikasi dan informasi secara fungsional. ${ }^{3}$

Kompetensi sosial merupakan kemampuan serta keterampilan sosial yang dimiliki oleh guru dalam menjalankan tugas dan tanggung jawabnya, dalam menyesuaikan diri terhadap tuntutan akan profesinya sebagai pendidik, serta kemampuan dan keterampilan komunikasi dan interaksi sosial dengan lingkungan sekitarnya baik di dalam maupun di luar lingkungan sekolah, di mana kemampuan atau keterampilan tersebut diperoleh guru melalui proses pembelajaran, pengalaman mengajar, serta kehidupan sosialnya. ${ }^{4}$

\section{Komponen Kompetensi Sosial Guru Kristen}

Kompetensi sosial merupakan kompetensi yang wajib dimiliki oleh setiap guru sebagai tenaga pendidik yang senantiasa berjumpa serta memengaruhi murid. Dalam kompetensi sosial, yang dituntut adalah kemampuan guru dalam berkomunikasi dan berinteraksi secara efektif dan efisien dengan peserta didik, sesama guru, orang tua atau wali peserta didik, dan warga sekitar. ${ }^{5}$

Menurut Badan Standarisasi Nasional Pendidikan, kompetensi sosial merupakan kemampuan pendidik sebagai bagian dari masyarakat untuk: (a) berkomunikasi lisan dan tulisan; (b) menggunakan teknologi komunikasi dan informasi secara fungsional; (c) bergaul secara efektif dengan peserta didik, sesama pendidik, tenaga kependidikan, orangtua/wali peserta didik;dan (d) bergaul secara santun dengan masyarakat sekitar. ${ }^{6}$

Han dan Kemple membagi komponen kompetensi sosial ke dalam enam bagian yaitu: 1) Self-regulation (pengaturan diri); 2) Interpersonal knowledge and skill (keterampilan dan pengetahuan interpersonal); 3) Cutural competence (pendekatan kemampuan berbudaya); 4) Adopting social values (Adaptasi nilai-nilai sosial); 5) Positive Self-identity (Identitas diri

3 Edison dkk., Sertifikasi Guru Dalam Jabatan/ Pengawas (Ambon: Lembaga Pendidikan Tenaga Kependidikan, 2012), 18.

4 Martina Tiku Rara, "Pengaruh Kompetensi Sosial Guru Kristen Bagi Pembentukan Karakter Murid Usia 10-12 Tahun Di SDN. 001 Mentarang Kab. Malinau, Kalimantan Utara." (Skripsi S.Th, Sekolah Tinggi Filsafat Theologia Jaffray, 2015), 4-5.

${ }^{5}$ Wahidmurni, Alfin Mustikawan, dan Ali Ridho, Evaluasi Pembelajaran Kompetensi dan Praktik (Yogyakarta: Nuha Litera, 2010), 5.

${ }^{6}$ Jejen Mustafah, Peningkatan Kompetensi Guru Melalui Pelatihan dan Sumber Belajar Teori dan Praktik, (Jakarta: Kencana, 2012), 52. Lihat Peraturan Pemerintah No. 74 Tahun 2008 tentang Guru, Bab II Pasal 3. 
yang positif); 6) Planning and decision-making skills (Keterampilan dalam perencanaan dan pengambilan keputusan). ${ }^{7}$

Dalam hubungannya dengan pelayanan guru PAK, kompetensi sosial diwujudkan lewat kemampuan mengomunikasikan nilai-nilai kebenaran Allah melalui komunikasi guru-siswa dalam proses pembelajaran PAK, mampu menggunakan informasi teknologi untuk mendukung pengajaran PAK, membangun persahabatan guru-siswa, dan membangun persaudaraan sebagai keluarga Allah dan membangun relasi dengan sesama dalam komunitas berbangsa dan bernegara.

\section{Kemampuan Komunikasi}

Kemampuan komunikasi sebagai sistem pengetahuan, keterampilan, motivasi, sikap dan sifat adalah kompetensi penting dari guru. ${ }^{8}$ Kemampuan komunikasi dianggap sebagai kemampuan seseorang untuk memilih perilaku komunikasi yang sesuai untuk mencapai tujuan hubungan sosial. ${ }^{9}$ Kompetensi (kemampuan) komunikasi mengintegrasikan dua dimensi, kognitif dan perilaku dan keterampilan dasar komunikasi (keterampilan kognitif dan keterampilan perilaku). ${ }^{10}$

Reardon menganggap dimensi kognitif kompetensi komunikasi sebagai konsep yang luas. Dimensi kognitif terdiri dari proses kesadaran dan proses kognitif dari informasi (kesadaran interpersonal, perspektif sosial, menangkap, konstruksi kognitif, pengawasan diri, empati, dan lain-lain). Dimensi Perilaku menunjukkan manifestasi yang berbeda dari kompetensi komunikasi (keterlibatan interaksi, fleksibilitas perilaku, mendengarkan, gaya komunikasi, dan komponen perilaku lainnya). ${ }^{11}$

Kemampuan komunikasi ini sangat penting dan harus dimiliki oleh seorang guru karena guru itu sendiri merupakan bagian dari sosial (masyarakat) di mana masyarakat sendiri adalah konsumen pendidikan.

7 Secara lengkap penjelasan komponen kompetensi sosial menurut Han dan Kemple terdapat dalam tulisan jurnal mereka. Heejeong Sophia Han and Kristen Mary Kemple, "Components of Social Competence and Strategies of Support: Considering What to Teach and How," Early Childhood Education Journal 34, No. 3 (December 2006): 241-243.

8 Lidija Zlatić, Dragana Bjekić, Snežana Marinković, Milevica Bojović, "Development of teacher communication competence," Procedia-Social and Behavioral Sciences 116 (2014):606 - 610.

9 Zlatic et al., "Development of teacher communication competence," 607; B. Spitzberg \& Cupach. W. R. Handbook of Interpersonal Competence Research, Recent Research in Psychology (Springer-Verlag, Publisher, 1989).

${ }^{10}$ Ibid., 607; K. K. Reardon, Interpersonalna komunikacija: Gdje se misli susreću (Zagreb: Alinea, 1998).

Il Ibid., 607. Zlatic et al. mengutip tulisan Reardon tentang komunikasi interpersonal dalam bahasa Kroasia (Interpersonalna komunikacija: Gdje se misli susreću, 76). 


\section{Kemampuan Penggunaan Teknologi Komunikasi dan Informasi}

Salah satu kemampuan atau keterampilan yang harus dimiliki oleh guru dalam kompetensi sosial ialah penggunaan alat informasi dan komunikasi secara fungsional. Dalam Peraturan Menteri Pendidikan Nasional Nomor 16 Tahun 2007 Tentang Standar Kualifikasi Akademik dan Kompetensi Guru dijelaskan bahwa guru harus Memanfaatkan teknologi informasi dan komunikasi untuk berkomunikasi dan mengembangkan diri yaitu menggunakan teknologi informasi dan komunikasi untuk kepentingan pembelajaran. ${ }^{12}$ Kemampuan ini juga termasuk dalam kompetensi profesional guru dalam memanfaatkan teknologi informasi dan komunikasi untuk mempermudah komunikasi dengan peserta didik dan manajemen kelas pembelajaran. Bagian ini dikenal juga sebagai keterampilan dan pengetahuan interpersonal (Interpersonal knowledge and skill).

Komisi Parlemen Eropa (2006) merekomendasikan delapan kompetensi kunci yang salah satunya adalah digital competence (kemampuan digital). Melek digital menjadi suatu keharusan, karena komputer sebagai alat melek informasi, membantu dalam memberikan dan bertukar informasi, komunikasi, pengembangan kerjasama jaringan. Jejaring sosial baru, seperti Facebook, Skype dan lain-lain merupakan sarana informasi yang dapat membantu masyarakat untuk berkomunikasi satu sama lain, berbagi informasi, dan akhirnya menghabiskan waktu luang mereka. Keterampilan ini membantu individu untuk meningkatkan cara berpikir kritis dan kreatif, untuk mengembangkan keterampilan penelusuran informasi. ${ }^{13}$ Kemampuan guru PAK dalam penggunaan teknologi informasi dan komunikasi akan berdampak pada kemampuan pengetahuan peserta didik dan pengembangan pribadi guru sendiri.

\section{Pergaulan yang Efektif}

Guru harus mengembangkan dan membangun nilai kerjasama melalui pergaulan yang baik dalam suatu tim. Orang yang berkompetensi secara sehat tahu menghargai dan menerima baik kekuatan maupun kelemahan sesamanya. Guru patut memampukan peserta didik untuk menerima keanekaragaman karya dan prakarsa dalam komunitas pembelajaran. Guru harus menciptakan dan membangun kualitas

\footnotetext{
${ }^{12}$ Peraturan Menteri Pendidikan Nasional Nomor 16 Tahun 2007 Tentang Standar Kualifikasi Akademik dan Kompetensi Guru.

${ }^{13}$ Genutè Gedvilienè, Social Competence of Teachers and Students The Case Study of Belgium and Lithuania (Kaunas, Lithuania: Vytautas Magnus University, 2012), 26-27.
} 
pergaulan yang efektif dan santun di kalangan para siswa, sesama pendidik dan masyarakat. ${ }^{14}$

Hubungan guru dan siswa dapat memengaruhi kompetensi sosial demikian pula sebaliknya. Bukti yang mendukung keduanya yaitu pengaruh hubungan guru-anak terhadap kompetensi sosial dan pengaruh kompetensi sosial terhadap hubungan guru-anak menunjukkan bahwa dua konstruksi mungkin menjadi timbal balik yang terkait. Beberapa model interaksi orang dewasa-anak juga mengandaikan pengaruh dua arah tersebut. Model Patterson menyarankan bahwa dalam interaksi antara anak dan orang dewasa yang signifikan (misalnya guru), di mana kedua belah pihak adalah peserta aktif. ${ }^{15}$ Hal ini sangat dimungkinkan terjadi dalam interaksi guru dan siswa (peserta didik) dalam proses pembelajaran dan interaksi sosial guru dan siswa di luar pembelajaran bersama dengan keluarga (orang tua siswa).

Hubungan anak dengan guru mencerminkan kualitas hubungan emosional antara kedua belah pihak. ${ }^{16}$ Hubungan anak dengan guru yang aman maka anak akan mendekati orang lain dengan sikap positif dan penuh harapan. Akibatnya, mereka akan lebih cenderung menjadi kompeten dalam membangun hubungan sosial. ${ }^{17}$ Sebaliknya, anak-anak dengan hubungan yang tidak aman akan membentuk model kerja negatif dalam dunia sosial dan akan cenderung untuk kurang menjadi kompeten dalam membangun hubungan sosial (Howes et al., 1994). ${ }^{18}$

Dari perspektif sosial-kognitif, guru yang memiliki kualitas interaksi guru-anak yang tinggi dapat memberikan dorongan kepada anak-anak dengan pendekatan model adaptif bagaimana untuk memecahkan masalah sosial dan mengajarkan keterampilan sosial dan kognitif yang tepat yang mendorong anak-anak dalam pengembangan kompetensi.

14 B. S. Sidjabat, Mengajar Secara Profesional: Mewujudkan Visi Guru Profesional (Bandung: Kalam Hidup, 2009), 121.

15 Xiao Zhang and Jari-Erik Nurmi, "Teacher-child relationships and social competence: A two-year longitudinal study of Chinese preschoolers," Journal of Applied Developmental Psychology 33 (2012):126; G. R. Patterson, Reid, J. B., \& Dishion, T. J. A social interactional approach. Antisocial boys, Vol. 4 (Eugene, OR: Castalia, 1992).

${ }^{16}$ C. A. Bergin \& D. A. Bergin, "Attachment in the classroom," Educational Psychology Review, 21 (2009):141-170.

17 Xiao Zhang and Jari-Erik Nurmi, "Teacher-child relationships and social competence: A two-year longitudinal study of Chinese preschoolers," Journal of Applied Developmental Psychology 33 (2012):125-126; B. K. Hamre \& R. C. Pianta, "Early teacherchild relationships and the trajectory of children's school outcomes through eighth grade," Child Development, 72, (2001):625-638.

18 Zhan and Nurmi, 126-127; C. Howes, C. E. Hamilton \& C. C. Matheson, "Children's relationships with peers: Differential association with aspects of the teacher-child relationship," Child Development, 65 (1994):253-263. 
Sebaliknya, kualitas interaksi rendah dapat membatasi kesiapan dan kemampuan guru untuk memberikan dukungan perilaku positif bagi perkembangan sosial anak-anak. ${ }^{19}$

\section{Hubungan Persaudaraan Sejati dan Semangat Kebersamaan}

Kompetensi sosial juga mencakup pemahaman kebutuhan dan perasaan orang lain, mengartikulasikan ide dan kebutuhan sendiri, memecahkan masalah, bekerja sama dan negosiasi, mengekspresikan emosi, "membaca" situasi sosial secara akurat, menyesuaikan perilaku untuk memenuhi tuntutan situasi sosial yang berbeda, memulai dan memelihara persaudaraan. ${ }^{20}$ Dalam pergaulan yang efektif diharapkan terjalin interaksi sosial antara guru dan siswa yang menjangkau kebutuhan emosional, kerjasama, menghargai perbedaan budaya dan perilaku siswa dan memulai persahabatan sebagai jembatan untuk mengenal secara pribadi kompetensi sosial peserta didik.

Dalam konteks pembelajaran, konsep membangun persaudaraan merupakan suatu hal yang sangat penting dalam membangun karakter siswa atau peserta didik. Para siswa dapat melihat dan merasakan hubungan yang terbina dengan baik antara sesama guru, akan termotivasi dalam diri perserta didik itu sendiri. Guru harus membangun sikap menghormati rekan sejawat, membimbing antar sesama rekan sejawat sebagai wujud membangun konsep persaudaraan yang efektif. ${ }^{21}$ Hal ini merupakan identitas diri positif yang terbentuk dalam diri seorang pendidik.

Bagi guru PAK dan seorang pendidik Kristen, syarat bagi munculnya perasaan-perasaan yang bersifat ilahi dan kudus sebagaimana yang dimiliki oleh Kristus adalah dipenuhi Roh Kudus dan menghasilkan buah Roh (Gal. 5:22-23). Bila guru PAK dipenuhi oleh Roh Kudus, maka tidak sulit baginya untuk secara spontan mengekspresikan perasaannya, menanggapi perasaan muridnya, menguasai dan mengarahkan

${ }^{19}$ Zhang and Nurmi, 125-126; E. O' Connor, E. Dearing \& B. A. Collins, "Teacherchild relationship and behavior problem trajectories in elementary school," American Educational Research Journal, 47 (2010):340-369.

20 Heejeong Sophia Han and Kristen Mary Kemple, "Components of Social Competence and Strategies of Support: Considering What to Teach and How," Early Childhood Education Journal 34, No. 3 (December 2006): 242; M. J. Kostelnik, A. P. Whiren, A. K. Soderman, L. C. Stein, \& K. Gregory, Guiding children's social development: Theory to practice, 4th ed. (New York: Delmar, 2002); L. Odom, C. Zercher, J. Marquart, S. Li, S. R. Sandall, \& P. Wolfberg, Social relationships of children with disabilities and their peers in inclusive preschool classrooms. In S. L. Odom (Ed.), Widening the circle: Including children withdisabilities in preschool programs (New York: Teachers College Press, 2002), 61-80.

${ }^{21}$ Daryanto, Standar Kompetensi dan Penilaian Kinerja Guru Profesional (Yogyakarta: Gava Media, 2013), 49. 
perasaannya, serta memberikan dirinya bagi Tuhan dan sesamanya. ${ }^{22}$ Hubungan emosional guru dan siswa yang terwujud dalam kasih Kristus sangat memungkinkan terjalinnya persaudaraan dan semangat kebersamaan.

\section{Perkembangan Karakter Siswa}

Istilah karakter (Inggris: character) berasal dari bahasa Yunani yaitu charassein yang berarti to engrave, kata ini bisa diterjemahkan mengukir, melukis, memahatkan, atau menggoreskan. Apa yang hendak ditekankan bahwa karakter adalah suatu tindakan sengaja untuk membentuknya layaknya tindakan memahat dan mengukir. ${ }^{23}$ Karakter mengacu pada pemotongan dan pengukiran yang tidak dilakukan hanya sekali tetapi sepanjang hidup yang berhubungan dengan niat dan hati secara utuh. Karakter dikembangkan sepanjang hidup seseorang, tetapi landasan karakter diletakkan dalam pelatihan moral anak usia balita melalui kebiasaan yang dibentuk oleh otoritas dan disiplin. ${ }^{24}$ Karakter diekspresikan melalui serangkaian sifat (misalnya kejujuran, ketekunan, tanggung jawab); namun, karakter tidak hanya jumlah dari sifat-sifat ini. Faktanya, sifat-sifat karakter tidak banyak menjadi penyusun karakter yang baik. Karakter itu sendiri adalah dasar seseorang untuk dibentuk dan menjadi bertahan dalam dirinya. ${ }^{25}$

Karakter selalu mengacu pada kebaikan yang terdiri dari tiga bagian yaitu mengetahui yang baik, menginginkan yang baik dan melakukan yang baik. Ketiga kebiasaan ini didasarkan pada kebiasaan pikiran, hati dan kehendak. Karakter sebagai sesuatu yang melekat pada personal, yaitu totalitas ide, aspirasi, sikap yang terdapat pada individu dan telah mengkristal di dalam pikiran dan tindakan. ${ }^{26}$

Karakter merupakan hasil dari perjalanan panjang pembentukan diri yang dipengaruhi oleh komitmen dan disiplin diri yang tinggi (secara internal) dan juga oleh pengaruh guru yang memiliki kompetensi yang berkualitas. Tidak dapat disangkal bahwa kualitas kompetensi yang

\footnotetext{
${ }^{22}$ Heman Elia, "Kehidupan Alam Perasaan Yesus Kristus Teladan Sempurna Bagi Para Pendidik Kristen," Veritas 2, No. 2 (Oktober 2001): 256.

${ }^{23}$ Heryanto, "Pendidikan Karakter: Teori Dan Praktis Dalam Pendidikan Kristen Di Indonesia," Stulos 12, No. 1 (April 2013):68; Kevin Ryan \& Karen E. Bohlin, Building Character in Schools: Practical Ways to Bring Moral Instruction to Life (San Fransisco: Jossey Bass, 1999).

${ }^{24}$ Judy Tenelshof, "Encouraging The Character Formation of Future Christian Leaders," Journal Of The Evangelical Theological Society 42/1 (March 1999): 77-90.

${ }^{25}$ Lorraine A. Potter, "The Character of Christ A Proposal for Excellence in Christian Character Education," (Thesis, Iowa State University, 2007), 3.

${ }^{26}$ Harapan Simatupang, "Revitalisasi Pendidikan Karakter: Sikap Dan Peran Serta Gereja pada Sekolah Negeri," Stulos 12/1 (April 2013):148.
} 
dimiliki oleh guru PAK dapat memberikan pengaruh terhadap pengembangan karakter siswa.

\section{Studi Hubungan kompetensi sosial Guru Kristen dan Perkembangan Karakter Siswa $^{27}$}

Dari hasil penelitian Selvianty Sari Bunga ini dapat dilihat sejauh mana pengaruh kompetensi sosial guru PAK terhadap perkembangan karakter siswa. Penelitian ini dilakukan di daerah Toraja dengan jumlah responden adalah 20 orang mewakili populasi guru-guru Kristen yang ada di SMK Rayon 1 Kabupaten Tana Toraja. Responden yang berjenis kelamin laki laki berjumlah 4 orang $(8 \%)$ dan responden yang berjenis kelamin perempuan berjumlah 16 orang (92\%). Usia responden antara 20-30 tahun sebanyak 3 orang (15\%), usia responden antara 31-40 tahun 15 orang (35\%), usia responden $41-50$ tahun sebanyak 10 orang (50\%), dan usia responden 51 tahun ke atas tidak ada. Tingkat pendidikan/kualifikasi guru bahwa responden yang berpendidikan Diploma tidak ada, responden yang berpendidikan S1 berjumlah 19 orang (95\%) dan responden yang berpendidikan S2 berjumlah l orang (5\%).

Sedangkan responden siswa SMK yang berjenis kelamin laki-laki berjumlah 36 orang (72\%) dan responden yang berjenis kelamin perempuan berjumlah 14 orang (28\%). usia responden 16 tahun sebanyak 2 orang (4\%), usia responden antara 17 tahun 20 orang (40\%), usia responden 18 tahun sebanyak 21 orang (42\%), dan usia responden 19 tahun sebanyak 7 orang (14\%).

Metode penelitian kuantitatif deskriptif dengan membagikan angket yang akan dijelaskan berdasarkan data yang diperoleh. Penjelasan mengenai hasil penelitian sebagai berikut.

Guru Kristen harus bisa berkomunikasi sehingga bisa berinteraksi dengan siswa yang akan membawa kepada interaksi bagaimana mereka dibimbing ke arah yang positif berada pada kategori baik dengan skor rata-rata dari setiap pertanyaan adalah 3,28.

Komunikasi memegang peranan penting di dalam pembelajaran karena akan membawa perubahan karakter yang baik pada seorang siswa di mana seorang guru bisa berkomunikasi dengan siswa membicarakan tentang kerohanian seorang siswa. Peranan komunikasi sangat berpengaruh pada perubahan karakter pada siswa secara spiritual. Komunikasi guru yang efektif berpengaruh positif kepada siswa dengan nilai rata-rata dari setiap pertanyaan kepada siswa memperoleh skor 3,09 yaitu kategori baik.

\footnotetext{
${ }^{27}$ Hasil penelitian Selvianty Sari Bunga tentang pengaruh kompetensi sosial guru Kristen terhadap karakter siswa SMK Rayon 1 Kabupaten Tana Toraja melalui pendekatan analisis deskriptif kuantitatif.
} 
Penguasaan teknologi di mana guru harus berusaha menguasai teknologi yang berhubungan dengan pembelajaran seperti penggunaan laptop/komputer atau perangkat teknologi informasi dan teknologi lainnya dengan berbagai programnya. Dengan penguasaan teknologi ini maka guru bisa mengarahkan siswa dengan metode yang kreatif dan menyenangkan sehingga siswa dapat lebih disiplin dalam mengikuti proses pembelajaran.

Dari hasil analisis angket yang disebarkan untuk guru ternyata hanya skor rata-rata dari beberapa pertanyaan yaitu 2,22 artinya berada pada kategori cukup baik dan pada pertanyaan siswa mencapai skor rata-rata dari setiap pertanyaan adalah 3,4l dengan kategori sangat baik.

Dapat dikatakan bahwa penguasaan teknologi sangat berpengaruh pada perkembangan karakter siswa dalam hal kedisiplinan dalam proses pembelajaran. Hasil ini menggambarkan bahwa tantangan guru Kristen untuk meningkatkan penguasaan teknologi informasi dan komunikasi dan pemahaman positif dan negatif tentang teknologi memengaruhi perkembangan karakter siswa yang adalah Youth Generation (Generasi Y). Pemahaman siswa tentang pentingnya penguasaan teknologi informasi dan komunikasi harus diimbangi oleh pendidik dalam hal ini guru Kristen.

Guru yang mampu bergaul secara efektif adalah guru yang bisa menempatkan dirinya sehingga di manapun ia berada, dia mampu untuk menjalin hubungan yang baik dengan orang-orang disekitarnya. Pengaruh yang signifikan dari kompetensi ini adalah karakter jujur akan terbangun dengan adanya bimbingan khusus dari guru dalam mengatasi permasalahan yang dihadapi oleh siswa. Kenyataan ini terlihat dari skor rata-rata dari setiap pertanyaan angket kepada guru yaitu 2,68 dengan kategori cukup baik dan skor rata-rata pada dari setiap pertanyaan kepada siswa yaitu 2,89 dengan kategori baik. Tantangan bagi guru adalah bagaimana membangun pergaulan dengan siswa sebagai sahabat di luar pembelajaran sehingga dapat memengaruhi siswa untuk bersikap jujur dalam kehidupannya dengan pertolongan Tuhan.

Indikator lainnya dari kompetensi sosial guru adalah penerapkan prinsip persaudaraan. Prinsip persaudaraan sangat penting di dalam sebuah wadah pendidikan guna untuk menjalin hubungan yang erat sesama rekan kerja termasuk dengan siswa. Dengan adanya prinsip persaudaraan, di mana guru guru dapat berperan sebagai sahabat dan orang tua bagi seorang siswa, akan dapat memampukan siswa untuk bisa dekat dan terbuka kepada guru. Sikap ini membuat terciptanya karakter siswa yaitu sikap bertanggung jawab.

Guru bisa meluangkan waktunya untuk membahas perkembangan siswa dengan orang tua dan juga siswa merasa tidak dibedakan oleh guru dalam membantu siswa mengatasi kesulitan belajarnya. 
Kompetensi ini membawa pengaruh pada perkembangan karakter siswa. Hal ini dapat dilihat dari skor rata-rata dari setiap pertanyaan pada guru yaitu 3,24 yaitu pada kategori baik sedangkan pada pertanyaan pada siswa mendapatkan skor rata-rata 3,22 yaitu baik. Interaksi sosial dan komunikasi guru dan orang tua siswa perlu diciptakan sedemikian rupa sehingga persoalan yang berhubungan dengan perkembangan siswa dapat dideteksi lebih awal untuk diberikan bimbingan tambahan dalam menghadapi pergumulannya sehingga karakternya dapat terbentuk dengan pertolongan Tuhan dan pendekatan pergaulan yang baik.

\section{Diskusi: Tantangan Pendidikan Kristen dalam Mencerdaskan Youth Generation}

Kompetensi sosial guru Kristen diperhadapkan dengan kemajuan teknologi informasi dan komunikasi yang berkembang dengan pesat. Sementara kompotensi sosial siswa sebagai Generasi Y yang sangat mahir menguasai teknologi informasi dan kebebasan untuk belajar dan memiliki teknologi memberikan tantangan bagi pendidikan Kristen. Siapakah yang lebih cerdas gurunya atau siswanya dalam kompetensi sosial? Sebab arah pendidikan dunia dipersiapkan untuk mencerdaskan generasi Y sebagai generasi masa akan datang yang unggul menghadapi persaingan bebas. Apa yang terjadi bila guru Kristen tidak berbenah diri dalam meningkatkan kompetensi sosialnya? Guru akan "digilas" oleh siswa yang memiliki kemampuan dalam penguasaan teknologi informasi dan komunikasi sebagai salah satu indikator dari kompetensi sosial. Bisa jadi siswa akan berbalik mendikte gurunya.

Guru-guru seharusnya lebih unggul dari anak-anak yang dipercayakan kepadanya, baik dalam hal pembimbingan karakter moral, dalam hal pengetahuan dari mata pelajaran yang diajarkan, dalam hal keterampilan praktis yang ditunjukkan melalui penggunaan sarana yang baik untuk mencapai tujuan, dan dalam hal kebijaksanaan yang diperlukan untuk menuntun kehidupan orang muda. ${ }^{28}$

Kompetensi sosial memediasi hubungan antara guru dan anak dan kompetensi sosial di rumah, dan perangkat tambahan kompetensi sosial harus ditekankan dalam pendidikan. Kompetensi sosial guru dapat ditingkatkan baik melalui pendidikan (misalnya pelatihan guru) dan remediasi (yaitu intervensi anak), yang pada gilirannya membawa ke program pengaturan lainnya. Namun program pendidikan berbasis sekolah menempatkan relatif sedikit penekanan pada intervensi anak atau membantu anak-anak memperoleh keterampilan sosial; sebaliknya, penekanan utama telah diletakkan pada kompetensi akademik anak-

${ }^{28}$ Harapan Simatupang, "Revitalisasi Pendidikan Karakter: Sikap dan Peran Serta Gereja pada Sekolah Negeri," Stulos 12/1 (April 2013):162. 
anak. ${ }^{29}$ Pendidikan Kristen sebaiknya tidak hanya merupakan program masa depan anak usia dini dalam penguasaan akademik, tetapi juga harus membantu anak-anak belajar bagaimana memecahkan masalahmasalah sosial dan berhasil berinteraksi secara efektif dengan orang lain.

Tantangan pendidikan Kristen berikutnya adalah hubungan sosial antara pendidik dan peserta didik. Kemajuan teknologi informasi dan komunikasi dapat mengurangi interaksi tatap muka sehingga di masa yang akan datang nilai-nilai sosial, moral dan spiritual hanyalah menjadi simbol pendidikan. Guru Kristen harus mampu membangun jembatan kompetensi sosial secara efektif, sehingga gap antara seorang guru dan siswa di masa yang akan semakin sempit dan mudah untuk memengaruhi Youth Generation dalam perkembangan karakter sejalan dengan kompentensi sosial (dalam hal ini penguasaan teknologi informasi dan komunikasi) yang terus berkembang.

\section{Kesimpulan}

Kompetensi sosial termasuk keterampilan dalam interaksi sosial dan melaksanakan tanggung jawab sosial, di mana kompetensi sosial memberi pengaruh dalam perkembangan karakter siswa dalam hal mempersiapkan peserta didik menjadi anggota masyarakat yang baik yang memiliki karakter yang baik terutama memiliki sikap hidup yang takut akan Tuhan, mengasihi Tuhan dan memiliki sikap hormat.

Youth Generation adalah generasi digital yang menuntut generasi pendahulunya dalam hal ini pendidik atau gurunya mengikuti perubahan yang pesat di bidang teknologi informasi. Di samping itu, kemudahan informasi dan kebebasan berkomunikasi di zaman sekarang menjadi tantangan yang harus dihadapi oleh guru Kristen dalam mendidik Generasi Y dan memajukan pendidikan Kristen dalam rangka mencapai tujuan pendidikan nasional yaitu mencerdaskan generasi muda penerus bangsa.

\section{Kepustakaan}

Bergin, C. A. and D. A. Bergin, "Attachment in the classroom." Educational Psychology Review, 21 (2009):141-170.

Bunga, Selvianty S., "Pengaruh Kompetensi Sosial Guru PAK Terhadap

Perkembangan Karakter Siswa di SMK Rayon 1 Kabupaten Tana

${ }^{29}$ Xiao Zhang and Jari-Erik Nurmi, "Teacher-child relationships and social competence: A two-year longitudinal study of Chinese preschoolers," Journal of Applied Developmental Psychology 33 (2012):134. 
Toraja." Tesis, M.Pd.K, Sekolah Tinggi Filsafat Theologia Jaffray, 2014.

Connor, E. O'., E. Dearing and B. A. Collins, "Teacher-child Relationship And Behavior Problem Trajectories in Elementary School." American Educational Research Journal, 47 (2010):340-369.

Daryanto, Standar Kompetensi dan Penilaian Kinerja Guru Profesional. Yogyakarta: Gava Media, 2013.

Edison, F. Thomas, Sjney Lisa Souisa, A. K. Sampeasang, Tjoa King Tjie, Agustina CH. Kakiay, Elka Anakota, dan Christiana D. W. Sahertian. Sertifikasi Guru Dalam Jabatan / Pengawas. Ambon: Lembaga Pendidikan Tenaga Kependidikan, 2012.

Elia, Heman. "Kehidupan Alam Perasaan Yesus Kristus Teladan Sempurna Bagi Para Pendidik Kristen." Veritas 2, No. 2 (Oktober 2001):249-257.

Gedvilienè, Genutè. Social Competence of Teachers and Students The Case Study of Belgium and Lithuania. Kaunas, Lithuania: Vytautas Magnus University, 2012.

Hamre, B. K. and R. C. Pianta, "Early teacher-child relationships and the trajectory of children's school outcomes through eighth grade." Child Development, 72, (2001):625-638.

Han, Heejeong S., and Kristen Mary Kemple, "Components of Social Competence and Strategies of Support: Considering What to Teach and How," Early Childhood Education Journal 34, No. 3 (December 2006): 24l-246.

Heryanto, "Pendidikan Karakter: Teori Dan Praktis Dalam Pendidikan Kristen Di Indonesia," Stulos 12, No. 1 (April 2013):65-96.

Howes, C., C. E. Hamilton and C. C. Matheson, "Children's relationships with peers: Differential association with aspects of the teacher-child relationship." Child Development, 65 (1994):253-263.

Judy Tenelshof, "Encouraging The Character Formation of Future Christian Leaders," Journal Of The Evangelical Theological Society 42/1 (March 1999): 77-90.

Kostelnik, M. J., A. P. Whiren, A. K. Soderman, L. C. Stein, \&\& K. Gregory, Guiding children's social development: Theory to practice, 4th ed. (New York: Delmar, 2002).

Leffert, N., P. L. Benson and J. L. Roehlkepartan, Starting out right: Developmental assets for children. Minneapolis, MN: Search Institute, 1997.

Mustafah, Jejen. Peningkatan Kompetensi Guru Melalui Pelatihan dan Sumber Belajar Teori dan Praktik. Jakarta: Kencana, 2012.

Odom, S. L. (Ed.), Widening the circle: Including children withdisabilities in preschool programs. New York:Teachers College Press, 2002. 
Patterson, G. R., J. B. Reid, and T. J. Dishion, A Social Interactional Approach. Antisocial Boys, Vol. 4. Eugene, OR: Castalia, 1992.

Peraturan Pemerintah No. 74 Tahun 2008 tentang Guru, Bab II Pasal 3.

Peraturan Menteri Pendidikan Nasional Nomor 16 Tahun 2007 Tentang Standar Kualifikasi Akademik dan Kompetensi Guru.

Potter, Lorraine A. "The Character of Christ A Proposal for Excellence in Christian Character Education." Thesis, Iowa State University, 2007. Diakses 15 Oktober 2016, http://digitalcollections.dordt.edu/cgi/viewcontent.cgi?article=1079 \&econtext=med_theses.

Rara, Martina Tiku. "Pengaruh Kompetensi Sosial Guru Kristen Bagi Pembentukan Karakter Murid Usia 10-12 Tahun Di SDN. 001 Mentarang Kabupaten Malinau Kalimantan Utara." Skripsi S.Th, Sekolah Tinggi Filsafat theologia Jaffray, 2015.

Reardon, K. K. Interpersonalna komunikacija: Gdje se misli susreću. Zagreb: Alinea, 1998.

Ryan, Kevin and Karen E. Bohlin, Building Character in Schools: Practical Ways to Bring Moral Instruction to Life. San Fransisco: Jossey Bass, 1999.

Sidjabat, B. S., Mengajar Secara Profesional: Mewujudkan Visi Guru Profesional Bandung: Kalam Hidup, 2009.

Simatupang, H. "Revitalisasi Pendidikan Karakter:Sikap Dan Peran Serta Gereja pada Sekolah Negeri.” Stulos 12/1 (April 2013):148.

Spitzberg, B. and Cupach. W. R. Handbook of Interpersonal Competence Research, Recent Research in Psychology.Springer-Verlag, Publisher, 1989.

Tenelshof, J. "Encouraging The Character Formation of Future Christian Leaders." Journal Of The Evangelical Theological Society 42/1 (March 1999): 77-90.

Undang-undang No. 2 Tahun 1989 tentang Sistem Pendidikan Nasional

Undang-undang No. 20 Tahun 2003 tentang Sistem Pendidikan Nasional

Wahidmurni, Alfin Mustikawan, dan Ali Ridho, Evaluasi Pembelajaran Kompetensi dan Praktik. Yogyakarta: Nuha Litera, 2010..

Zhang, Xiao and Jari-Erik Nurmi, "Teacher-child relationships and social competence: A two-year longitudinal study of Chinese preschoolers." Journal of Applied Developmental Psychology 33 (2012):125-135.

Zlatić, L., Dragana Bjekić, Snežana Marinković, Milevica Bojović, "Development of teacher communication competence." ProcediaSocial and Behavioral Sciences 116 (2014):606 - 610. 